\title{
Linguistic Impediments of Communicative Proficiency: A Case Study of Students in the CSHS, Shaqra University, Thadiq, KSA
}

\author{
Hatim Hassan Tawfiq ${ }^{1} \&$ Abdelshafie Alrayeh Abdelshafie $^{1}$ \\ ${ }^{1}$ College of Sciences and Humanity Studies, Shaqra University, Thadiq, Saudi Arabia \\ Correspondence: Hatim Hassan Tawfiq, College of Sciences and Humanity Studies, Shaqra University, Thadiq, \\ Saudi Arabia.
}

Received: September 22, 2021

Accepted: October 18, 2021

Online Published: October 19, 2021

doi: 10.5539/elt.v14n11p61

URL: https://doi.org/10.5539/elt.v14n11p61

\begin{abstract}
This paper examines the linguistic barriers that impede English language communicative proficiency of the students of English language in the college of sciences and humanity studies, Thadiq, Shaqra University, Saudi Arabia. The paper gives the specific linguistic problems that detain attaining a perfect English language communicative competence. The paper also examines the teaching strategies that help students reach competency in oral skill. It concludes with some suggestions that help students to achieve a higher proficiency in English language communication.
\end{abstract}

Keywords: communicative proficiency, linguistic impediments, oral skill, teaching strategies

\section{Introduction}

The persistence increasing number of people who are using English for global communication around the world makes English the language of international communication. The most remarkable fact is that the majority of the people who have learned English to communicate are multilingual speakers and they are more than the native people whose first language is English. (Kirkpatrick, 2007) At Present, English is the most widely language that is taught as a foreign language in more than hundred countries including all African and Asian countries where it develops particular roles that give it a special status.

\subsection{Statement of the Problem}

The problem of the study is to see why students fail to achieve perfect proficiency in speaking skill. Students produce only short turns and responses, and they don't give extended answers to express themselves. The researcher assumes that the insufficient lexicon and the limited knowledge of grammar are complicating factors for this problem.

\subsection{Questions of the Study}

The study hypothesizes that existence of some language barriers affect communicative proficiency, and it also hypothesizes that inappropriate methods, approaches, and strategies adopted in teaching speaking skills hinder communicative proficiency. The questions below has been stated to manage the paper:

1) What makes English language proficiency unattainable?

2) What are the appropriate methods and approaches that help students reach a higher communicative proficiency?

\subsection{Significance of the Study}

Investigation of language barriers that impede communicative proficiency raises awareness of difficulties that face students to attain a perfect communicative proficiency, which in turn, gives recommendations that help reaching communicative proficiency.

\subsection{Literature Review}

It is stated that a language becomes global when it is used as a medium of communication in the governmental domains such as the law courts, the educational systems, and media. This is the case of English language in countries like Nigeria, Ghana, India, and so many other countries where it is used as the official language. (Crystal, 2003) English is practically used as the intermediary language (lingua franca) by people who already 
have their own languages for multiple reasons such as business, education, diplomacy, tourism, etc. All around the globe people learn English simply because it is worthwhile. (Schneider, 2011)

Speaking results from social, mental, and articulatory processes. Talking about a topic requires content and linguistic knowledge which are coded into sounding and linguistic patterns that travel to the listeners for comprehension. It also requires attention to the context of interaction to choose the proper diction which makes potential understanding. Speeches are produced to perform acts, so competent speakers should have a speaking function skill. The pronunciation skill is also as important as the speaking function skill because it makes speeches comprehensible. The interaction management is another factor that makes a speaker competent. A speaker needs to regulate the speeches he makes according to the context of the conversation. So, some of the factors that make a speaker competent are pronunciation, interaction management, and speech function skill. (Goh, 2016) There are cognitive, metacognitive, and interactional strategies for communication. The cognitive strategies involves paraphrasing, for example describing an object or a person, and approximation in which a speaker uses alternative terminologies. The metacognitive strategies involves planning, self-monitoring and evaluation, the preparation a speaker makes to produce the speech, and the self-correction of the language he produces. The interactional strategies entails the explanation that the speaker utters to make the speech intelligible. (Goh \& Burns, 2012)

One of the major challenges of a foreign language learner is to figure out the sound bits of the target language. (Thorin, Sadakata, Desain, \& McQueend, 2017) An Arabic language utterance is acoustically organized in a way that is different from English language utterance. Thus, it is natural that a language learner finds it difficult to figure out the sounds of a foreign language. There is a need for much practice, phonetic training, and proper teaching strategies of pronunciation to reach a higher perceptive and productive competence. Fluency in speaking English language requires ability to pronounce phonemes correctly and necessitates appropriate use of stress and intonation patterns. (Harmer, 2015) It is not only pronunciation and correct phonological production of language that matters in teaching speaking skill, but there is also another communicative aspect which is more important in teaching speaking skill, the need to distinguish between the different situations in which a speaker communicate. The language that a teacher uses in class when teaching speaking skill is also another essential matter. Teachers' clear language is important as it controls everything that is going on in class. Speech modification is one of the outstanding features of classroom discourse. In some situations, a teacher's talk is similar to the language that a student finds in his speech with his family. It is sometimes louder, slower, and containing many pauses. The main reason for that is the student's need to understand what they are learning. Teachers control the classroom discourse by the type of questions that they give in class. The type of questions are either displaying questions, in which students display their ideas, or referential questions which promote discussions and help learners produce longer responses and expressions. (Walsh, 2011)

Emotional reactions to speaking anxiety is a major problem that second language learners undergo. Concentration problems while speaking, perplexed mind, and voice change are some of the problems that learners experience when learning speaking skill. Adult learners feel frustrated when they fail to express themselves correctly. So, teaching strategies that teachers adopt while teaching speaking skill should consider the students problems of anxiety. (Marzec-Stawiarska, 2015)

\section{Method}

The paper is a case study conducted in the college of sciences and humanity studies. There is only one instrument adopted to assess the hypotheses of the study. A students' questionnaire has been formed to see the linguistic impediments and the inappropriate teaching methods and strategies that restrain students' progress in communicative competence. The statistical package for social sciences (SPSS) has been utilized to analyze the statements of the students' questionnaire. The sample of the study contains fresh students that has been enrolled in the department of English language and business administration in the college of sciences and humanity studies at Shaqra University. All of the students involved in the questionnaire are at an initial stage of English language education.

\section{Results}

The subjects' responses to the statements regarding the first hypothesis: "language barriers affect communicative proficiency" revealed the following results: Difficulties in pronouncing some new vocabulary are the most problematic area of this regard. Limitation of students' vocabulary comes as a second factor that affect students' communicative competence negatively. Similarities in meaning of some English words and limited knowledge of grammar represent the third and the fourth obstacles consequently. For the statements concerning methods, approaches and strategies used in teaching and learning speaking skill, the results show repetition of sounds of 
unfamiliar words and performing situational conversations in the classroom help a lot in enhancing the communicative proficiency. Watching English movies, listening to CDs, and watching videos before starting speaking activities are useful strategies that improve speaking skill.

\section{Discussion}

Data were analyzed and correlated on the basis of the figures that are extracted from SPSS as shown in the tables below. The first table shows the reliability of the questionnaire which is statistically significant at all levels.

Table 1. Reliability

\begin{tabular}{ll}
\hline Cronbach's Alpha & N. of Items \\
\hline .865 & 15 \\
\hline
\end{tabular}

The descriptive statistics were calculated for all variables of the study using the statistical package for social sciences to assess the hypotheses of the study. The section below discusses the results of the first hypothesis which assumes that existence of some language barriers affect communicative proficiency.

\subsection{First Hypothesis}

Table 2. Existence of some language barriers affect communicative proficiency

\begin{tabular}{lll}
\hline Condition & mean & Std.D. \\
\hline $\begin{array}{l}\text { My limited knowledge of English language grammar makes it difficult for me to master speaking } \\
\text { skill. }\end{array}$ & 3.23 & 1.292 \\
I find it difficult to participate in speaking activities because my lexicon is insufficient. & 3.35 & 1.263 \\
I find difficulty in mastering speaking skill because English vocabulary contains words that are & 3.27 & 1.300 \\
$\begin{array}{l}\text { similar in meaning. } \\
\text { The difficult pronunciation of some vocabulary makes it so hard for me to master speaking skill. }\end{array}$ & 3.44 & 1.219 \\
\hline
\end{tabular}

A questionnaire has been formed and distributed to students of English language at the college of sciences and humanity studies to see their perceptions on the existence of some language barriers that affect communicative proficiency. The table above shows the means and the standard deviations of the statements that evaluate the existence of the language barriers affecting communicative proficiency. It appears that the difficult pronunciation of some vocabulary makes communicative proficiency so hard for students to master speaking skill. The value extracted from the statistical package about the statement is 3.44. The second higher value which reveals students perception on language barriers that hinders attaining communicative proficiency is 3.35 . Students believe that their English language lexicon is insufficient and that it detains arriving to a perfect level of communicative proficiency. Some students think that the difficulty in mastering speaking skill is due to the fact that in English language vocabulary there are some synonyms that make confusion in their choices of the appropriate lexicon when speaking. The mean value of that statement 3.27. The belief that limited knowledge of English language grammar obscures communicative proficiency got 3.23 which is the lowest mean in the table above. A few number of the sample of the study believes that grammar knowledge hinders reaching a perfect level of speaking skill. 


\subsection{Second Hypothesis}

Table 3. The inappropriate methods, approaches and strategies adopted in teaching speaking skills hinder communicative proficiency.

\begin{tabular}{llc}
\hline Condition & mean & Std.D. \\
\hline My classroom is noisy, and it is hard to follow my teachers' instructions. & 2.79 & 1.557 \\
Our teacher plays CDs and videos before starting the speaking activity. & 3.67 & 1.191 \\
$\begin{array}{l}\text { My classroom contains cooperative classmates who help me while doing the speaking } \\
\text { activity. }\end{array}$ & 3.52 & 1.185 \\
$\begin{array}{l}\text { Our teacher always asks us to use and repeat the sounds of words and expressions that } \\
\text { learned in class. }\end{array}$ & 3.92 & 1.127 \\
$\begin{array}{l}\text { Our teacher usually rewards us after performing a speaking activity. } \\
\text { Our English curriculum contains enough materials for speaking skill. }\end{array}$ & 3.31 & 1.240 \\
$\begin{array}{l}\text { I always practice English conversations outside my class. } \\
\text { Our teacher always asks us to watch English movies/ shows with subtitles. }\end{array}$ & 3.75 & 1.082 \\
Our teacher makes us use gestures when we cannot find the words in English language during & 3.83 & 1.219 \\
speaking activities. & 3.25 & 1.078 \\
$\begin{array}{l}\text { Mistakes, during speaking activities, makes me seem like a weaker student, so I always avoid } \\
\text { speaking in oral activities. }\end{array}$ & 2.96 & 1.557 \\
Our teacher always use flash cards to make us remember English words and expressions. & 3.31 & 1.223 \\
\hline
\end{tabular}

The study hypothesizes that the inappropriate methods, approaches, and strategies adopted in teaching speaking skills hinder communicative proficiency. The questionnaire of the students contains eleven statements that test the hypothesis above. The statements reflect students' perceptions of the methods, approaches and strategies adopted in teaching speaking skills. The values of means and standard deviations are shown above. The highest value - 3.92 shows that teachers always ask students to use and repeat the sounds of the new words and expressions that have been learned in class. The second highest value - 3.83 shows that teachers always ask students to watch English movies/ shows with subtitles. Students believe that movies/ shows equipped with subtitles help them mastering the speaking skill. The majority of the students think that their English language syllabus contains enough materials for speaking skill. The stable above shows a mean of 3.75 for that. CDs and videos before starting speaking skill appears to be advantageous when teaching speaking skill. The table shows 3.67 for the statement "Our teacher plays CDs and videos before starting the speaking activity." Practice outside class seems to be of more importance to students. Most of the students believe that the more practice they make outside class, the more perfect they are in speaking skill. There is a value of 3.56 for the statement "I always practice English conversations outside my class." The statement "My classroom contains cooperative classmates who help me while doing the speaking activity' got 3.52. Students believe that co-work in speaking activities helps them share ideas and speak in the classroom. Rewarding after performing a speaking activity and using flash cards to make students remember English words and expressions, encourage students to give better performance at speaking activities. The table shows a value of 3.31 for that. Forcing students to use the target language helps them to proceed successfully in speaking skill. The statement 'teachers make students use gestures when they cannot find the words in English language during speaking activities' got a value of 3.35 in the table above. A few number of the students believe that mistakes, during speaking activities, make them look like a weaker student. The table shows only 2.96 for the statement:" Mistakes, during speaking activities, makes me seem like a weaker student, so I always avoid speaking in oral activities." The least value of the statements in the table above is 2.79 which is given to the statement: "My classroom is noisy, and it is hard to follow my teachers' instructions."

\section{Conclusion}

All in all, learners' aptitude to learn pronunciation, lexicon, and linguistic structures helps achieving higher progress in communicative proficiency. The inappropriate methods and strategies of teaching speaking skills detain communicative proficiency. The descriptions below are among the preferable teaching strategies that help mastering speaking skill: 
1) CDs and videos that are presented before starting speaking skill are useful when teaching speaking skill.

2) Subtitles attached with movies/ shows help Ss mastering the speaking skill.

3) Rewarding after performing a speaking activity and using flash cards make Ss remember English words and expressions and forces them to give better performance at speaking activities.

4) Repetition of the sounds of words and expressions that have been learned in class.

5) Practice outside class.

\section{Acknowledgement}

The researchers would like to thank all colleagues and students at the department of English language and the students of Business Administration at the college of sciences and humanity studies, Shaqra University, Thadiq, Saudi Arabia.

\section{References}

Crystal, D. (2003). English as a Global Language. Cambridge: Cambridge University Press. https://doi.org/10.1017/CBO9780511486999

Goh, C. C. M. (2016). Teaching Speaking. In Renandya, W. \& Widodo, H. (Eds.), English Language Teaching Today (pp. 143-159). English Language Education, vol 5. Springer, Cham. https://doi.org/10.1007/978-3-319-38834-2_11

Goh, C. C. M., \& Burns, A. (2012). Teaching Speaking A holistic Approach. New York: Cambridge.

Harmer, J. (2015). The Practice of English Language Teaching. London: Pearson. https://doi.org/10.1093/elt/ccx060

Kirkpatrick, A. (2007). World Englishes: Implications for international communication and English language teaching. Cambridge: Cambridge University Press. https://doi.org/10.1093/elt/ccn002

Marzec-Stawiarska, M. (2015). Investigating Foreign Language Speaking Anxiety Among Advanced Learners of English. In Pawlak, M. \& Waniek-Klimczak, E. (Eds.), Issues in Teaching, Learning and Testing Speaking in a Second Language. Second Language Learning and Teaching. Springer, Berlin, Heidelberg. https://doi.org/10.1007/978-3-642-38339-7_7

Schneider, E. W. (2011). English Around the World: An Introduction. Cambridge: Cambridge University Press. https://doi.org/10.1075/eww.33.1.06wee

Thorin, J., Sadakata, M., Desain, P., \& McQueend, J. M. (2017). Perception and production in interaction during non-native. The Journal of the Acoustical Society of America, 92, 103. https://doi.org/10.1121/1.5044415

UR, P. (2012). A Course in English Language Teaching. Cambridge: Cambridge University Press. https://doi.org/10.1017/9781009024518

Walsh, S. (2011). Exploring Classroom Discourse: Language in Action (1st ed.). Routledge. https://doi.org/10.4324/9780203827826

\section{Copyrights}

Copyright for this article is retained by the author(s), with first publication rights granted to the journal.

This is an open-access article distributed under the terms and conditions of the Creative Commons Attribution license (http://creativecommons.org/licenses/by/4.0/). 